\title{
Limonene, a Chemical Compound Related to the Resistance of Eucalyptus Species to Austropuccinia psidii
}

\author{
Renata R. Silva, ${ }^{1}$ André C. da Silva, ${ }^{2, \dagger}$ Roberto A. Rodella, ${ }^{3}$ Márcia O. M. Marques, ${ }^{4}$ Antônio J. V. Zanuncio, ${ }^{5}$ Marcus A. Soares, ${ }^{6}$ \\ José E. Serrão, ${ }^{7}$ José C. Zanuncio, ${ }^{8}$ and Edson L. Furtado ${ }^{1}$ \\ ${ }^{1}$ Departamento de Produção Vegetal, Faculdade de Ciências Agronômicas, Universidade Estadual Paulista, Botucatu, 18610-307 \\ São Paulo, Brasil \\ ${ }^{2}$ Departamento de Fitossanidade, Universidade Federal do Rio Grande do Sul, Porto Alegre, 91540-000 Rio Grande do Sul, \\ Brasil \\ ${ }^{3}$ Departamento de Botânica, Instituto de Biociências de Botucatu, Universidade Estadual Paulista, Botucatu, 18618-000 São \\ Paulo, Brasil \\ ${ }^{4}$ Centro de Pesquisa de Recursos Genéticos Vegetais, Instituto Agronômico de Campinas, Campinas, 13020-902 São Paulo, \\ Brasil \\ ${ }^{5}$ Departamento de Engenharia Florestal, Universidade Federal de Viçosa, Viçosa, 36570-900 Minas Gerais, Brasil \\ ${ }^{6}$ Programa de Pós-Graduação em Produção Vegetal, Universidade Federal dos Vales Jequitinhonha e Mucuri, Diamantina, \\ 39100-000 Minas Gerais, Brasil \\ ${ }^{7}$ Departamento de Biologia Geral, Universidade Federal de Viçosa, Viçosa, 36570-900 Minas Gerais, Brasil \\ ${ }^{8}$ Departamento de Entomologia/BIOAGRO, Universidade Federal de Viçosa, Viçosa, 36570-900 Minas Gerais, Brazil
}

\begin{abstract}
The fungus Austropuccinia psidii is a major pathogen of Eucalyptus spp. that damages mainly early-stage leaves. Resistant clones are the most widely used control measure for the rust disease caused by $A$. psidii. Essential oils produced in the plant-host cells are associated with resistance. However, the chemical characteristics of Eucalyptus leaves at different stages of maturity, associated with resistance or susceptibility to $A$. psidii, need to be determined. The aims of this study were to characterize the chemical composition of essential oils in Eucalyptus leaves at three developmental stages of clones of three E. urophylla $\times E$. grandis hybrids that exhibit different resistance levels to rust and to identify probable resistance-related compounds from them.

chromatography coupled with mass spectrometry. No rust was observed on the three leaf stages of the resistant clone or on the fifth leaf stage of the susceptible clones. Limonene was found at high percentages in essential oils from the three leaf stages of the resistant clone and at low percentages in the susceptible clones. In vitro and in vivo tests indicated that low limonene percentages stimulated A. psidii urediniospore germination and were not fungitoxic, whereas high percentages caused complete inhibition of germination and degenerative changes in fungal reproductive structures. The limonene present in $E \mathbf{E}$ calyptus leaves can be considered a chemical compound related to the rust resistance of Eucalyptus spp.
\end{abstract} The rust severity following inoculation and the quantity and quality of the essential oil extracted by hydrodistillation were determined at the first, third, and fifth leaf stages of the three clones. Identification of the compounds present in the essential oil was determined by gas
Keywords: Eucalyptus essential oils, eucalyptus rust, gas chromatography, phenology stage, Puccinia psidii, resistance, secondary metabolism
The fungus Austropuccinia psidii (G. Winter) Beenken, family Sphaerophragmiaceae (Pucciniales) [Beenken, L. (2017)], is native to South and Central America (Alfenas et al. 2005). A. psidii causes eucalyptus rust, one of the most harmful diseases and a major threat to Myrtaceae biodiversity and especially to the Eucalyptus forestry industry worldwide (Coutinho et al. 1998; Pérez et al. 2011). This pathogen has been reported on four continents (Machado et al. 2015). Together with the wide host range of this fungus (Eucalyptus

${ }^{\dagger}$ Corresponding author: A. C. da Silva; andrec_agro@yahoo.com.br

Funding: This work was supported by the Conselho Nacional de Desenvolvimento Científico e Tecnológico (CNPq), Coordenação de Aperfeiçoamento de Pessoal de Nível Superior (CAPES) (finance code 001), Fundação de Amparo à Pesquisa do Estado de Minas Gerais (FAPEMIG), and Instituto de Pesquisas e Estudos Florestais (IPEF) of Brazil Programa Cooperativo sobre Proteção Florestal (PROTEF).

*The $\boldsymbol{e}$-Xtra logo stands for "electronic extra" and indicates that one supplementary figure is published online.

The author(s) declare no conflict of interest.

Accepted for publication 23 August 2019.

(C) 2020 The American Phytopathological Society spp., Eugenia cambucae, Eugenia koolauensis, Eugenia uniflora, Melaleuca spp., Metrosideros polymorpha, Myrcianthes fragrans, Myrciaria cauliflora, Psidium guajava, and Syzygium jambos, among other Myrtaceae species), this pathogen is of considerable global importance (Coutinho et al. 1998; da Silva et al. 2014a; Glen et al. 2007). This rust can occur in nursery cuttings and younger trees in the field, causing damage and crop losses (Coutinho et al. 1998; Silva et al. 2013). Planting of elite clones of Eucalyptus species (e.g., E. grandis, E. cloeziana, E. dunnii, E. benthamii, E. phaeotricha, E. globulus, E. viminalis, and E. nitens) has been limited because of their high susceptibility to this pathogen (Alfenas et al. 2009; Glen et al. 2007).

Genetic host resistance is the main strategy for managing A. psidii (Mamani et al. 2010). Several rust-resistant genetic materials have been identified (Dianese et al. 1986; Santos et al. 2014; Silva et al. 2013), but little is known about the resistance mechanisms of Eucalyptus plants to this disease. Genetic (Junghans et al. 2003; Laia et al. 2015; Mamani et al. 2010), chemical (Boava et al. 2010; Taylor and Mims 1991), and structural (Santos et al. 2019; Silva et al. 2017; Xavier et al. 2015) factors associated with plant resistance to A. psidii have been reported, but there are currently no studies showing an interaction between the essential oils present in the Eucalyptus leaf and resistance to this rust.

Plants produce secondary metabolites useful in their interaction with the environment, such as the development of resistance against 
pathogens and tolerance to various abiotic stresses (Sudha and Ravishankar 2002). Compounds derived from secondary metabolism, including essential oils, have impressive biological activities ranging from antibiotic, insecticidal, to pharmaceutical activity (Stockigt et al. 1995). Awareness of the functions of these compounds in plants has led to new studies in the last decade (Sudha and Ravishankar 2002).

Essential oils are composed of various chemical compounds (Batish et al. 2006). The essential oil of Eucalyptus leaves has volatile organic acids, alcohols, aldehydes, esters, hydrocarbons, and ketones, which are predominantly mono- and sesquiterpenes (Batish et al. 2008; Elaissi et al. 2010). The chemical composition of plant essential oils is genetically determined and may vary according to species, individual, organ of synthesis, phenological stage, and leaf age (Batish et al. 2006; Brooker and Kleinig 2006). Moreover, essential oil bioactivity depends on the type, nature, and concentration of its constituents (Batish et al. 2008). Therefore, Eucalyptus essential oils and their main constituents could be used in the management of phytopathogens such as fungi (Pereira et al. 2011; Vilela et al. 2009), bacteria (Amorim et al. 2011), and nematodes (Andrés et al. 2012). Regarding fungal pathogens, Eucalyptus essential oils have been reported to reduce mycelial growth (Fiori et al. 2000) and inhibit spore production (Fiori et al. 2000; Oluma and Garba 2004).

A. psidii infects only young tissues of susceptible Eucalyptus plants (Silva et al. 2017; Xavier et al. 2001). There is a gradual reduction in the process of penetration, establishment, and reproduction of A. psidii in Eucalyptus leaves as the leaf ages (Silva et al. 2017; Xavier et al. 2001, 2015). The relationship between the essential oil composition in Eucalyptus clones and differential resistance to rust, as well as between leaf phenological stages and resistance to A. psidii, needs to be clarified. In addition, essential oil compounds in different Eucalyptus clones and in leaf phenological stages may be associated with resistance to rust disease.

Our objectives in this study were to characterize the chemical composition of essential oils in leaves of clones of three $E$. urophylla $\times E$. grandis hybrids with different levels of resistance to $A$. psidii, at three developmental stages, and to identify putative resistance-related compounds in these hybrids.

\section{Materials and Methods}

Plant material and evaluation of leaf-stage resistance. Clones of three E. urophylla $\times$ E. grandis (Myrtales, Myrtaceae) hybrids were selected based on their response to A. psidii in field tests at Votorantim Celulose and Papel S.A. Company (Jacareí, SP, Brazil; $23^{\circ} 17^{\prime} \mathrm{S}$ and $\left.45^{\circ} 54^{\prime} \mathrm{W}\right)$. Cuttings of clones C041A, VR3748, and TC31 were considered to be resistant, susceptible, and highly susceptible to $A$. psidii, respectively, and were supplied by Votorantim Celulose and Papel S.A. Cuttings of the three hybrid clones were grown in 2-liter-capacity pots containing Carolina Soil (Carolina Soil do Brasil, Santa Cruz do Sul, RS, Brazil) substrate enriched with simple superphosphate $\left(6 \mathrm{~kg} / \mathrm{m}^{3}\right)$ and Osmocote $\left(1.5 \mathrm{~kg} / \mathrm{m}^{3}\right.$, NPK 19:06: 10; Tecnutri do Brasil, Tietê, SP, Brazil) and kept in a greenhouse at 20 to $32^{\circ} \mathrm{C}$ for 50 days. Plants were then transferred to the growth chamber $\left(23 \pm 3^{\circ} \mathrm{C}\right.$ temperature, 12 -h light/12-h dark photoperiod) and inoculated with an isolate of A. psidii (FCA-PP2303) obtained from the mycological collection of the Universidade Estadual Paulista Laboratory of Forest Pathology. To increase the concentration of urediniospores for inoculation tests, young leaves of Syzygium jambos (L.) Alston were inoculated until runoff with a suspension of $1 \times 10^{6}$ urediniospores $/ \mathrm{ml}$ using a manual sprayer with a conical ejection nozzle. The inoculated plants were incubated at $23 \pm 3^{\circ} \mathrm{C}$ in a growth chamber under continuous darkness for $24 \mathrm{~h}$, followed by a 12 -h photoperiod. After 12 days, newly formed urediniospores were collected using a fine brush and stored at $-80^{\circ} \mathrm{C}$. We then used a hemocytometer to prepare an inoculum of $1 \%$ Tween 20 in water at a concentration of $1 \times 10^{6}$ urediniospores $/ \mathrm{ml}$ and sprayed the plants as previously described. After inoculation, the plants were kept in darkness for $24 \mathrm{~h}$, followed by a 12-h light/dark photoperiod. Eight days after inoculation, disease severity (number of pustules $/ 2 \mathrm{~cm}^{2}$ of leaf area previously marked on the middle third of each leaf) was evaluated on the first, third, and fifth leaf pairs from the apex to the base of each Eucalyptus clone. The experiment was carried out using a completely randomized design with 10 replications (one cutting per replication).

Extraction and analysis of essential oils. We selected 1-year-old plants from clones C041A, VR3748, and TC31 grown in the municipality of Jacareí, São Paulo, Brazil $\left(23^{\circ} 17^{\prime}\right.$ S and $\left.45^{\circ} 54^{\prime} \mathrm{W}\right)$ under the same edaphoclimatic and silvicultural conditions to evaluate the chemical composition of their essential oils. Healthy leaves of the first, third, and fifth pairs of leaves at the same phenological stage were collected from 20 plants per clone per replication in the morning during July 2010. Essential oils were extracted from $200 \mathrm{~g}$ of fresh leaves per leaf stage, clone, and replication. The leaves were cut and transferred to a Clevenger apparatus for hydrodistillation. The essential oil collected after $2 \mathrm{~h}$ of hydrodistillation was separated and stored at $-40^{\circ} \mathrm{C}$ in flasks covered with aluminum foil (da Silva et al. 2014b). The oil yield was expressed as oil volume (in milliliters) per $100 \mathrm{~g}$ of sample. The experimental design consisted of completely randomized blocks with three replications per clone (20 plants per clone per replication).

Oil samples were analyzed by gas chromatography (GC) with flame ionization detection (FID) using a Shimadzu model 17A chromatograph (Kyoto, Japan) and by GC-mass spectrometry (MS) in a Shimadzu model QP5000 instrument with a quadrupole detector. All analyses were carried out using a DB-5 fused-silica column $(30 \mathrm{~m} \times 0.25 \mathrm{~mm}$ i.d., $0.25 \mu \mathrm{m}$ film thickness; J \&W Scientific Inc.). The chromatographic conditions were as follows: initial temperature of $60^{\circ} \mathrm{C}$ increasing to $240^{\circ} \mathrm{C}$ at $3{ }^{\circ} \mathrm{C} \mathrm{min}^{-1}$, helium carrier gas at a flow rate of $1.0 \mathrm{ml} \mathrm{min}^{-1}$, injector temperature at $220^{\circ} \mathrm{C}$, injection volume of $1.0 \mu \mathrm{l}$, flow ratio of $1: 20$, interface temperature of $230^{\circ} \mathrm{C}$, ionization potential of $70 \mathrm{eV}$, mass range of 40 to $550 \mathrm{~m} / z$, and scan rate of 0.84 scans s $^{-1}$. The compounds were identified by comparing their MS profiles with those of the National Institute of Standards and Technology (1998) online library and literature databases (Adams 2007). The retention indices (RIs) were obtained with a series of $n$-alkanes $\left(\mathrm{C}_{8}\right.$ to $\left.\mathrm{C}_{32}\right)$ chromatographed under conditions analogous to those of the samples using the equation proposed by Van den Dool and Kratz (1963). Retention values were then compared with those reported in the literature (Adams 2007). We used GC/FID to detect the relative concentrations of essential oil components by the area normalization method without considering specific response factors.

Fungitoxicity of limonene on urediniospores of $\boldsymbol{A}$. psidii. The toxic effect of the main constituent found in the essential oil from each of the three phenological stages of the clone resistant to A. psidii was evaluated in a spore germination bioassay test. Infected Eucalyptus leaves were collected 20 days after inoculation with the same isolate (FCA-PP2303) of A. psidii used before, and a spore suspension in water containing $1 \%$ Tween 20 was prepared at a concentration of $1 \times 10^{5}$ spores $/ \mathrm{ml}$. The GC analysis identified a high concentration of limonene in the Eucalyptus essential oil of the resistant clone. Pure samples of $(R)-(+)-$ limonene (183164; Sigma-Aldrich, St. Louis, MO) and $(S)-(-)$-limonene (218367-50G; Sigma-Aldrich) were then tested at concentrations of $1,10,100,1,000$, and 10,000 ppm. A limonene/water premix was prepared using Tween 20 emulsifier at $1 \%$ to produce the concentrated emulsions. One milliliter of the emulsion was mixed with $4 \mathrm{ml}$ of water agar previously autoclaved at $121^{\circ} \mathrm{C}$ for $20 \mathrm{~min}$ and poured into 5 -cm-diameter Petri dishes (da Silva et al. 2012). Medium for the negative control was prepared in the same manner but omitting the essential oils. After the agar solidified, $70 \mu \mathrm{l}$ of the spore suspension was spread on the agar medium in each dish. The samples were incubated in the dark for $48 \mathrm{~h}$ at $23^{\circ} \mathrm{C}$. The spore germination percentage was then evaluated with a light microscope. Each Petri dish was divided into four quadrants; 50 spores per quadrant, totaling 200 spores per dish, were scored as germinated or nongerminated. The experiment was a completely randomized design with three replications (one Petri dish per replication) and repeated once.

Fungitoxicity of limonene on rust in Eucalyptus plants. Cuttings of the rust-susceptible clone (VR3748) were grown in 2-liter-capacity 
pots and kept in a greenhouse at 20 to $30^{\circ} \mathrm{C}$ for 50 days as previously described. The plants were then transferred to the growth chamber $\left(23 \pm 3{ }^{\circ} \mathrm{C}\right.$ temperature, 12 -h/12-h light/dark photoperiod) where they were inoculated with the FCA-PP2303 isolate in a suspension in water containing $1 \%$ Tween 20 at a concentration of $1 \times 10^{6}$ urediniospores $/ \mathrm{ml}$. After inoculation, the plants were kept in the dark for $24 \mathrm{~h}$ followed by a 12 -h photoperiod. Fifteen days after inoculation, the plants (one plant per treatment) were sprayed with either $(R)-(+)$ - or $(S)-(-)$-limonene at concentrations of 1, 10, 100, 1,000 , and $10,000 \mathrm{ppm}$. In the control treatment, plants were sprayed with only water containing $1 \%$ Tween 20 . Seventy-two hours after the treatment application, five leaves inoculated with the pathogen per treatment were collected for analysis by scanning electron microscopy (SEM). Sample preparation and analysis followed previous methods (Silva et al. 2017).

Statistical analysis. Data from the evaluation of resistance of the leaf stages of the Eucalyptus clones were submitted to factorial analysis constituted by the combination of three clones $\times$ three leaf stages. The data were transformed $(x+0.5)^{1 / 2}$ following the procedure described by Box and Cox (1964) to obtain data normality and were then submitted to analysis of variance (ANOVA). Mean values, when significant, were compared using the Tukey test. The percentage data of the essential oil composition for the first, third, and fifth leaf stages from the three clones were submitted to multivariate statistical tests of cluster and principal component analyses (Sneath and Sokal 1973) to correlate them with resistance or susceptibility to A. psidii. The multivariate statistical clustering and principal component analyses were carried out for the most abundant substances for better visualization and to carry out Pearson's product-moment correlation between the factors. Performance data were submitted to ANOVA, followed by the Tukey test. The germination test was performed in a factorial analysis consisting of the combination of the two limonenes $(R$ and $S) \times$ six concentrations. A regression analysis was also performed on the limonene concentrations against spore germination, with the standard error of the regression coefficient also being calculated. The normality and homogeneity of variance was evaluated on the residuals and no

Table 1. Severity of Austropuccinia psidii on leaves of the first, third, and fifth phenological stages (E1, E3, and E5) from the resistant (C041A), susceptible (VR3748), and highly susceptible (TC31) clones of Eucalyptus urophylla $\times$ E. grandis $^{\mathrm{Y}}$

\begin{tabular}{lccc}
\hline & \multicolumn{3}{c}{ Leaf phenological stage } \\
\cline { 2 - 4 } Clone & $\mathbf{E 1}^{\mathbf{z}}$ & $\mathbf{E 3}$ & $\mathbf{E 5}$ \\
\hline TC31 & $18.3 \mathrm{aA}$ & $9.3 \mathrm{aB}$ & $0 \mathrm{aC}$ \\
VR3748 & $4.8 \mathrm{bA}$ & $0.8 \mathrm{bB}$ & $0 \mathrm{aB}$ \\
C041A & $0 \mathrm{cA}$ & $0 \mathrm{bA}$ & $0 \mathrm{aA}$ \\
\hline
\end{tabular}

y Data are presented as the mean number of pustules $/ 2 \mathrm{~cm}^{2}$ of leaf area. Means followed by the same small letter per column or capital letter per line do not differ by the Tukey test at $5 \%$. For statistical analysis, data were transformed to $(x+0.5)^{1 / 2}$. Data are presented in their actual values. Significant minimum difference $=0.3976$.

${ }^{\mathrm{z}}$ Mean E1, E3, and E5 values were obtained from 10 replicates.

Table 2. Total yield of essential oils per $100 \mathrm{~g}$ of leaves of the first, third, and fifth phenological stages (E1, E3, and E5) from the resistant (C041A), susceptible (VR3748), and highly susceptible (TC31) clones of Eucalyptus urophylla $\times E$. grandis determined by gas chromatography/mass spectrometry analysis $^{\mathrm{y}}$

\begin{tabular}{lccc}
\hline & \multicolumn{3}{c}{ Leaf phenological stage } \\
\cline { 2 - 4 } Clone & $\mathbf{E 1}^{\mathbf{z}}$ & $\mathbf{E 3}$ & $\mathbf{E 5}$ \\
\hline C041A & $1.61 \mathrm{aB}$ & $2.28 \mathrm{aA}$ & $1.88 \mathrm{aB}$ \\
VR3748 & $1.44 \mathrm{aB}$ & $1.60 \mathrm{bAB}$ & $1.85 \mathrm{aA}$ \\
TC31 & $0.85 \mathrm{bC}$ & $1.35 \mathrm{bB}$ & $1.82 \mathrm{aA}$ \\
\hline
\end{tabular}

${ }^{\mathrm{y}}$ Data are presented as means in milliliters per $100 \mathrm{~g}$ of leaves. Means followed by the same small letter per column or capital letter per line do not differ by the Tukey test at $5 \%$. Significant minimum difference $=0.277$.

${ }^{\mathrm{z}}$ Mean E1, E3, and E5 values were obtained from three replicates. deviations from normality were found, based on the presuppositions applied to the analysis. The statistical analyses were performed using $\mathrm{R}$ software (R Development Core Team).

\section{Results}

Natural Eucalyptus infection by A. psidii was evaluated in young trees up to 1 year old in field tests at Votorantim Celulose and Papel S.A. Disease scores were based on the scale by Zamprogno et al (2008) as follows: S0, no pustules or healthy plants; S1, isolated punctate pustules on the limbs and young leaves; S2, rust pustules generally sparse or occasionally abundant on the limbs and young leaves; and S3, pustules abundant on the limbs, petioles and leaves, at the tips of branches and the primary stem, and apical necrosis). The C041A clone was resistant to rust (S0), the VR3748 clone was susceptible (S2), and the TC31 clone was highly susceptible (S3). In the evaluation of resistance according to the leaf stages of the three $E u$ calyptus clones, no pustules were observed on the three phenological leaf stages of the resistant clone (Table 1). In the highly susceptible and susceptible clones, a decrease in the number of pustules per square centimeter of leaf area was observed with increasing leaf age. The disease was not observed at the fifth leaf stage of any of the three clones tested. The first leaf stage of the highly susceptible and susceptible clones had higher infection levels than the third and fifth leaf stages of their clones. The first and third leaf stages of the highly susceptible clone had the highest densities of rust pustules.

The resistant clone had higher essential oil yields at the first and third leaf stages than the susceptible and highly susceptible clones (Table 2). At the fifth leaf stage, oil production was similar among the three Eucalyptus clones. The resistant clone produced the highest oil yield at the third leaf stage, the susceptible clone had similar yields in the third and fifth leaf stages, and the highly susceptible clone exhibited an increasing essential oil yield from the first to the fifth phenological stages.

Chemical analysis of the essential oils extracted from the three leaf stages of the three Eucalyptus clones showed that monoterpenes were the main constituents, followed by sesquiterpenes (trans-caryophyllene and viridiflorene) (Table 3). Moreover, limonene (29 to 33.87\%), $\alpha$-pinene (19 to $20.62 \%$ ), and 1,8 -cineole (18 to $24.45 \%$ ) were the major essential oil compounds in all three phenological leaf stages of the resistant clone (Table 3). In the susceptible clone, 1,8-cineole (35 to $40.47 \%$ ), $\alpha$-pinene (33 to $41.31 \%$ ), and $\alpha$-terpineol (4 to $5.54 \%$ ) were the major compounds. The highly susceptible clone showed 1,8 -cineole (21 to $35.14 \%$ ), $\gamma$-terpinene (15 to $19.91 \%$ ), and $\alpha$-pinene (15 to $18.08 \%$ ) as the principal compounds. For the susceptible and highly susceptible clones, $\alpha$-pinene and 1,8-cineole were the major compounds at all three leaf phenological stages. Limonene, however, had the highest concentrations in the three leaf phenological stages of the resistant clone.

The first principal component analysis (Table 4) with the graphic dispersion (Fig. 1) showed higher $\gamma$-terpinene, $\alpha$-terpinyl acetate, ortho-cymene, 4-terpineol, and terpinolene percentages and lower $\alpha$-pinene levels in the three leaf stages of the clone highly susceptible to the disease. For the second principal component, the resistant clone was distinguished by higher percentages of limonene and lower 1,8-cineole levels in the essential oils from its three leaf stages. The correlation between the 13 major and two main (Y1 and Y2) compounds of the essential oils showed that the resistant clone was separated from the susceptible and highly susceptible ones along axis Y2, which accounted for approximately $25 \%$ of the variation in oil composition (Fig. 1; Table 4). Limonene was the major influence on axis Y2, consistent with the hypothesis that limonene concentration is important for rust resistance (Table 4) and could potentially be selected for resistance tests. The highly susceptible clone was separated from the susceptible and resistant clones along axis Y1, which accounted for approximately $55 \%$ of the variation, yet the major discriminant along axis Y1 was ortho-cymene; the resistant and susceptible clones overlap along this axis (Fig. 1; Table 4).

The graphic dispersion (Fig. 1) and dendrogram resulting from cluster analyses of the 13 compounds of the essential oils (Supplementary Fig. S1) showed differences among both clones and the leaf 
phenological stages. The chemical composition and relative proportions of compounds in the oils grouped the three clones into different clades (Fig. 1 and Supplementary Fig. S1). The highly susceptible clone showed marked dissimilarity compared with the susceptible and resistant clones (Fig. 1). A similar effect was also identified among the phenological leaf stages. Leaves of the first phenological stage (most susceptible) differed from those of the third and fifth stages (less susceptible) in all clones (Fig. 1). This supported the hypothesis of a relationship between the essential oil composition and Eucalyptus resistance to the fungus A. psidii.

No difference was detected between experiments conducted to evaluate the fungitoxicity of limonene on urediniospore germination, so the data obtained were combined. The in vitro test evaluated limonenes at concentrations of $1,10,100,1,000$, and 10,000 ppm. There was no difference between the $R$ and $S$ enantiomers, nor was there any interaction between the limonene enantiomers and their concentrations in terms of spore germination. A difference was observed only at doses of both compounds. $(R)-(+)$-limonene and the $(S)-(-)-$ limonene at concentrations of 1 or $10 \mathrm{ppm}$ stimulated fungus germination to rates of 146 and $164 \%$ and 55 and 84\%, respectively, in relation to germination in the control treatment (Fig. 2). The limonene enantiomers $R$ and $S$ at concentrations of $100,1,000$, or $10,000 \mathrm{ppm}$ produced $100 \%$ inhibition of urediniospore germination.

The fungitoxic effects of $R$ and $S$ limonene enantiomers on eucalyptus rust were confirmed using SEM (Figs. 3 and 4). Limonene at concentrations $>100 \mathrm{ppm}$ caused morphological changes to the fungus. Degeneration in the urediniospore cell wall and collapse of the urediniospores, teliospores, and paraphyses were the main changes observed in the pustules. No changes in fungus morphology were observed in the control treatment and in limonene tested at concentrations of 1 and $10 \mathrm{ppm}$.

\section{Discussion}

Our analysis of rust severity, yield of essential oils, and oil composition emphasized the differences in resistance among the three Eucalyptus clones and their leaf stages. Multivariate statistical analysis differentiated among the three Eucalyptus clones and the first leaf stage, indicating possible relationships among the essential oil concentrations and their constituents as well as the incidence and severity of $A$. psidii. The youngest (first leaf stage) Eucalyptus leaves were the most susceptible to A. psidii (Silva et al. 2017; Xavier et al. 2001). The susceptible and highly susceptible clones had a lower essential oil yield in the first and third leaf pairs. The resistant clone with no symptoms of rust at all leaf stages tested had higher essential oil yield in the first and third leaf stages than the susceptible and highly susceptible ones. Oil yield was similar among the three Eucalyptus clones at the fifth leaf stage. The fifth leaf stage is resistant to A. psidii independent of intrinsic resistance or susceptibility to the fungus (Silva et al. 2017; Xavier et al. 2015). The lower pathogen occurrence and similar oil yield at the fifth leaf stage of all three of the clones suggests that high quantities of essential oils may be involved in plant defense, as reported for the leaf disease pathosystem Eucalyptus globulus-Mycosphaerella (Hantao et al. 2014).

The essential oil constituents of the resistant, susceptible, and highly susceptible Eucalyptus clones in the three phenological leaf stages were similar but with variations in their relative concentrations. This may be attributable to their common genetic parentage, E. urophylla $\times E$. grandis. Therefore, resistance or susceptibility to A. psidii may be related to the percentage of each compound in the essential oil in different clones and different leaf phenological stages. Limonene was found at high concentrations in the essential oil extracted from the three-leaf stages of the resistant clone and at low concentrations in the leaves of the susceptible and highly susceptible clones. Limonene is a compound with a broad action spectrum against fungi and bacteria (Aggarwal et al. 2002; Regnier et al. 2008; Singh et al. 2010), although its low ability to inhibit some pathogens has been reported (Combrinck et al. 2011).

The effectiveness of limonene depends on its concentration and on the target pathogen (Combrinck et al. 2011; Droby et al. 2008; Eckert et al. 1984). Limonene at low concentrations (1 and $10 \mathrm{ppm})$ in the culture medium stimulated spore germination. This was probably attributable to the perception of biochemical signals by A. psidii urediniospores, since limonene is a component of the Eucalyptus leaf. Oil

Table 4. Correlation coefficients between 13 chemical compounds of essential oils present in three leaf stages (E1, E3, and E5) of three Eucalyptus urophylla $\times$ E. grandis clones and their two principal components (Y1 and Y2)

\begin{tabular}{lccrc}
\hline Chemical compound & Y1 & Ordination $^{\mathbf{z}}$ & Y2 & Ordination $^{\text {Yrone }}$ \\
\hline$\alpha$-pinene & -0.7118 & 6 & -0.6984 & 3 \\
$\alpha$-phellandrene & -0.6315 & 8 & 0.6486 & 4 \\
Ortho-cymene & 0.9711 & 1 & 0.1510 & 11 \\
Limonene & -0.4220 & 10 & 0.9000 & 1 \\
1,8-cineole & -0.1454 & 12 & -0.8474 & 2 \\
cis- $\beta$-ocimene & 0.1102 & 13 & -0.4328 & 5 \\
$\gamma$-terpinene & 0.9698 & 2 & -0.1207 & 12 \\
Terpinolene & 0.7963 & 5 & 0.0881 & 13 \\
4-terpineol & 0.8766 & 4 & 0.2169 & 10 \\
$\alpha$-terpineol & -0.6402 & 7 & -0.4092 & 6 \\
$\alpha$-terpinyl acetate & 0.9174 & 3 & 0.3870 & 8 \\
trans-caryophyllene & 0.2697 & 11 & 0.3930 & 7 \\
Viridiflorene & 0.5939 & 9 & -0.2320 & 9 \\
Retained information $(\%)$ & 54.88 & & 24.53 & \\
Accumulated information & 54.88 & & 79.41 & \\
\hline
\end{tabular}

${ }^{\mathrm{z}}$ Ordination of substances as the discriminatory power.

Table 3. Chemical compounds of essential oils present in three leaf stages (E1, E3, and E5) of Eucalyptus urophylla $\times$ E. grandis clones C041A (resistant), VR3748 (susceptible), and TC31 (highly susceptible) to Austropuccinia psidii ${ }^{\mathrm{y}}$

\begin{tabular}{|c|c|c|c|c|c|c|c|c|c|c|c|}
\hline \multirow[b]{2}{*}{ Chemical compound } & \multicolumn{3}{|c|}{ Clone C041A } & \multicolumn{3}{|c|}{ Clone VR3748 } & \multicolumn{3}{|c|}{ Clone TC31 } & \multicolumn{2}{|c|}{ Retention index } \\
\hline & E1 & $\mathbf{E 3}$ & E5 & E1 & $\mathbf{E 3}$ & E5 & E1 & E3 & E5 & Calculated & Lit. $^{\mathrm{z}}$ \\
\hline$\alpha$-pinene & 20.62 & 19.88 & 20.24 & 33.55 & 39.64 & 41.31 & 15.33 & 17.29 & 18.08 & 932 & 939 \\
\hline$\alpha$-phellandrene & 2.88 & 4.41 & 2.77 & 2.97 & 1.44 & 1.13 & 0.81 & 0.67 & 0.49 & 1004 & 1005 \\
\hline Ortho-cymene & 0.96 & 1.35 & 1.79 & 0.83 & 0.49 & 0.43 & 3.89 & 3.28 & 3.17 & 1021 & 1022 \\
\hline Limonene & 29.37 & 33.87 & 33.22 & 4.77 & 4.65 & 4.16 & 2.94 & 3.45 & 3.53 & 1027 & 1031 \\
\hline 1,8-cineole & 18.56 & 22.0 & 27.45 & 35.08 & 38.97 & 40.47 & 21.93 & 33.91 & 35.14 & 1028 & 1033 \\
\hline cis- $\beta$-ocimene & 2.19 & 1.37 & 0.85 & 3.80 & 2.10 & 1.65 & 2.93 & 2.13 & 1.45 & 1034 & 1040 \\
\hline$\gamma$-terpinene & 0.40 & 0.51 & 0.46 & 0.18 & 0.21 & 0.24 & 15.14 & 19.31 & 19.91 & 1056 & 1062 \\
\hline Terpinolene & 0.88 & 0.63 & 0.60 & 0.97 & 0.40 & 0.35 & 1.77 & 1.14 & 0.90 & 1086 & 1088 \\
\hline 4-terpineol & 0.74 & 0.75 & 0.90 & 0.22 & 0.29 & 0.34 & 1.18 & 1.63 & 2.04 & 1172 & 1177 \\
\hline$\alpha$-terpineol & 5.10 & 3.54 & 2.73 & 4.55 & 5.54 & 5.16 & 3.93 & 2.35 & 2.71 & 1186 & 1189 \\
\hline$\alpha$-terpinyl acetate & 3.19 & 3.40 & 3.21 & 0.64 & 0.27 & 0.18 & 6.79 & 5.69 & 6.03 & 1345 & 1350 \\
\hline trans-caryophyllene & 1.92 & 1.22 & 0.50 & 1.23 & 0.67 & 0.37 & 1.70 & 1.08 & 0.71 & 1417 & 1418 \\
\hline Viridiflorene & 1.29 & 0.41 & 0.28 & 2.24 & 0.88 & 0.52 & 3.59 & 1.71 & 1.04 & 1493 & 1493 \\
\hline
\end{tabular}

${ }^{y}$ Mean values are given in percentages and were obtained from three replicates.

${ }^{\mathrm{z}}$ Literature, Adams (2007). 
from the peels of several citrus species and volatiles emitted from injured oranges were responsible for stimulating germination of Penicillium digitatum conidia, and this was also found to be related to the limonene component of the citrus essential oil (Droby et al. 2008; Eckert et al. 1984; French et al. 1978).

Chemical substances released on the leaf surface can stimulate fungal germination (Parbery and Blakeman 1978). However, the stimulation of fungal germination by volatile compounds present in essential oils depends on their concentration (Droby et al. 2008). Citral strongly stimulated $P$. digitatum germination at concentrations

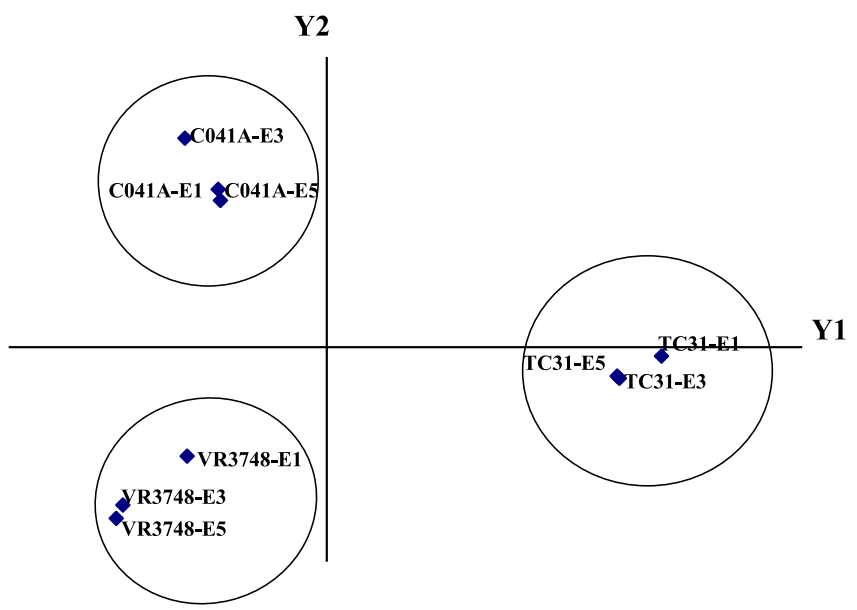

Fig. 1. Graphic dispersion of the three Eucalyptus clones and the three leaf phenological stages using the two first principal components ( $Y 1$ and $Y 2)$ for the group of 13 major chemical compounds of the essential oils. C041A, resistant clone; VR3748, susceptible clone; and TC31, highly susceptible clone. E1, E3, and E5 are the first, third, and fifth leaf stages, respectively. equivalent to 0.06 to $0.15 \mathrm{ppm}$ but completely inhibited it at higher concentrations (Droby et al. 2008). P. italicum germination was stimulated over a wider range of concentrations (from 0.06 to $1.5 \mathrm{ppm}$ ) and complete inhibition was not evident until the citral concentration reached 15 ppm (Droby et al. 2008). In in vitro testing, limonene inhibited $100 \%$ of $A$. psidii urediniospore germination at concentrations $>100 \mathrm{ppm}$. In the in vivo test, concentrations of limonene $>100$ ppm caused degenerative changes in the morphology of the urediniospores, teliospores, and paraphyses present in rust pustules, confirming the fungitoxic capacity of limonene when present at higher concentrations. No changes in fungal morphology were observed at lower concentrations of this compound. Essential oils can alter the morphology of a fungus by their fungitoxic action, such as oils from Aloysia gratissima, Cordia verbenacea, and Hyptis marrubioides on Asian soybean rust (da Silva et al. 2014b) and on eucalyptus powdery mildew (da Silva et al. 2014c). Our study is the first report showing the degenerative effect of limonene on fungal reproductive structures.

Although the fifth leaf stage of the susceptible and highly susceptible clones had no signs or symptoms of rust, only a low concentration of limonene was found. However, there was a high concentration of essential oil. Little is known about how optimum concentrations, and activity in general, may be affected (additively, synergistically, or negatively) by other compounds present in essential oils (Droby et al. 2008). The increased resistance of these leaves to disease may be linked to a set of interrelated factors, such as the high concentration of essential oil, where compounds at high concentrations may exhibit synergistic effects (Droby et al. 2008), or by physical (Silva et al. 2017; Xavier et al. 2015) or biochemical barriers present in leaves (Boava et al. 2010; Taylor and Mims 1991) as previously reported.

The effect of limonene in the clone resistant to A. psidii may also have been synergistically intensified by other leaf components, increasing its inhibitory capacity (Romagnoli et al. 2005; Sharma

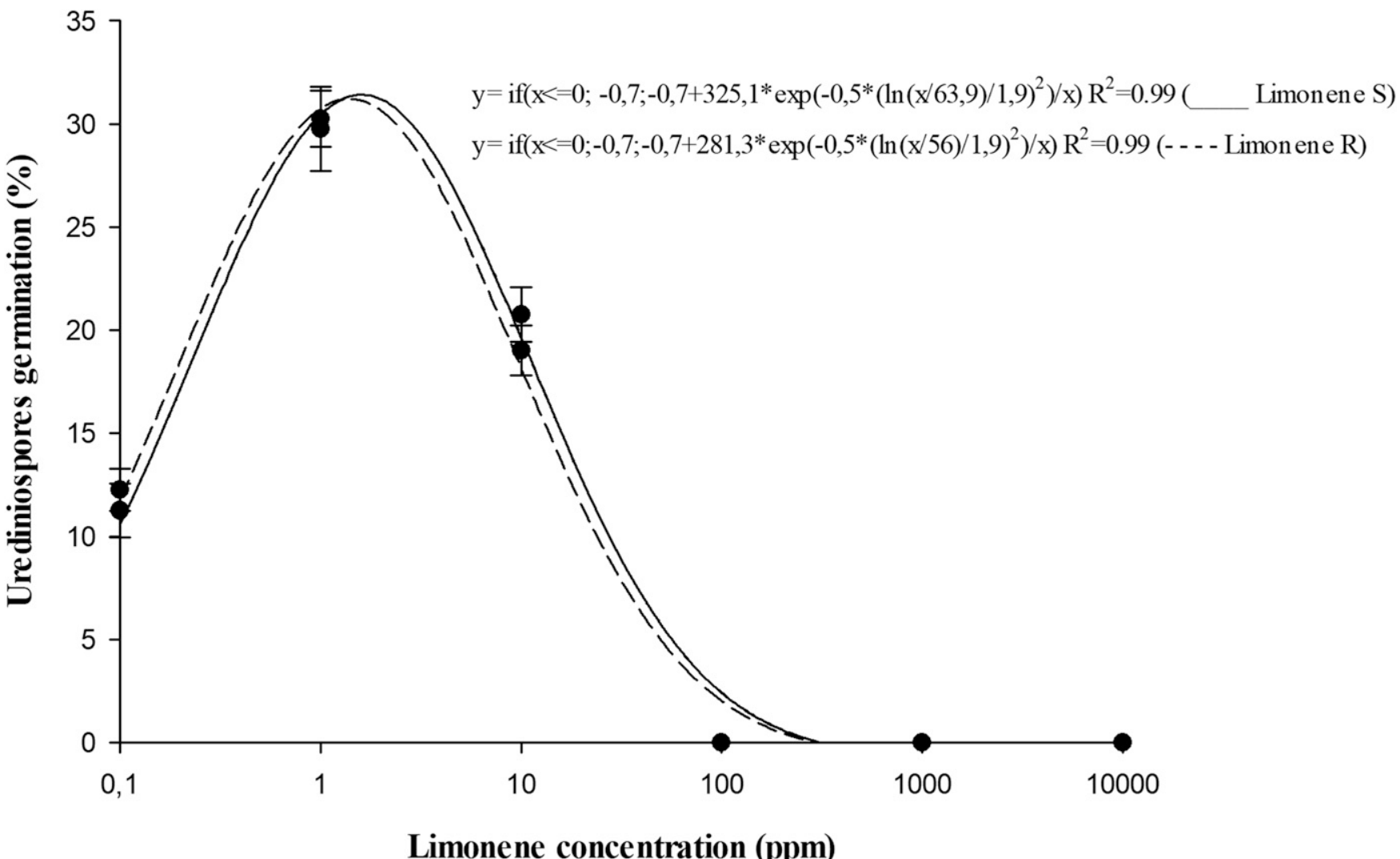

Fig. 2. Percentage of Austropuccinia psidii urediniospore germination on agar medium containing different concentrations of $(R)-(+)-$-limonene and $(S)-(-)-$ limonene. Germination percentage was assessed from 200 spores in each of three replicate Petri dishes for each treatment. 
and Tripathi 2006). The components of oil from Melaleuca alternifolia, except $\beta$-myrcene, have antifungal activity and 4-terpineol, $\alpha$-terpineol, linalool, and $\alpha$ and $\beta$-pinene, followed by 1,8-cineole, inhibit the growth of various fungal species (Hammer et al. 2003). D-limonene, cineole, $\beta$-myrcene, $\alpha$-pinene, $\beta$-pinene, and camphor exhibited high levels of inhibitory activity against Botrytis cinerea (Wilson et al. 1997). The monoterpenes, E-anethole, p-anisaldehyde, carvacrol, carvone, 1,8-cineole, limonene, myrcene, $\alpha$-phellandrene, and $\alpha$-pinene inhibit the germination of the fungi $B$. cinerea, Monilinia laxa, Mucor piriformis, Penicillium expansum, $P$. digitatum, $P$. italicum, and Rhizopus stolonifer (Caccioni and Guizzardi 1994). Our in vitro and in vivo tests showed that limonene concentrations above a certain threshold were damaging to $A$. psidii urediniospores, but testing additional compounds present in high concentrations
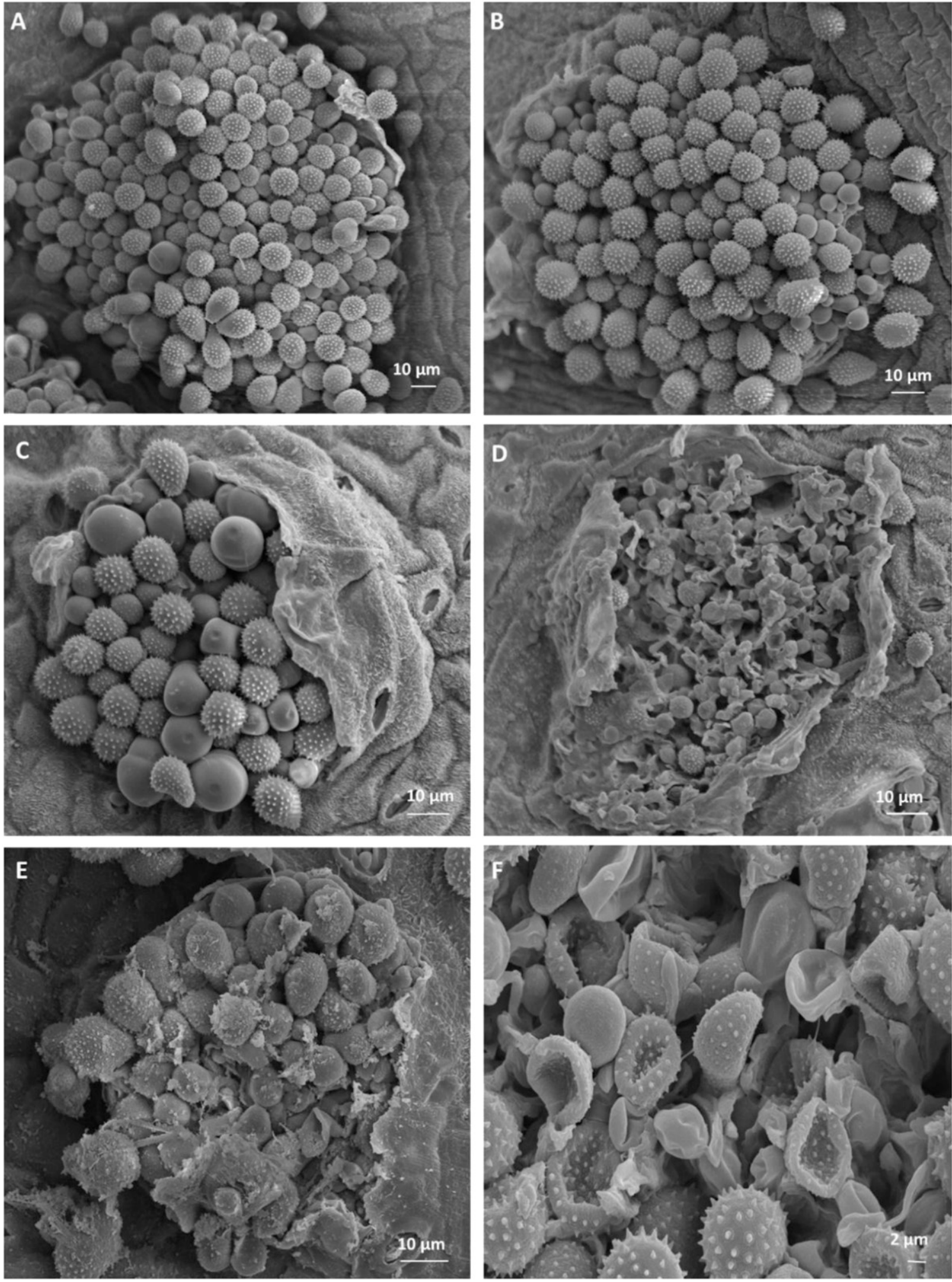

Fig. 3. Scanning electron microscopy images of Austropuccinia psidii pustules on Eucalyptus leaves treated with A, water containing $1 \%$ Tween 20 used as a control, B, (S)(+)-limonene at $1 \mathrm{ppm}, \mathbf{C}, 10 \mathrm{ppm}, \mathbf{D}, 100 \mathrm{ppm}, \mathbf{E}, 1,000 \mathrm{ppm}$, and F, 10,000 ppm. At concentrations above $100 \mathrm{ppm}$, degeneration was observed in the urediniospore cell wall and collapse of the urediniospores, teliospores, and paraphyses. In the control treatment and at dosages of 1 and $10 \mathrm{ppm}$, no morphological changes were observed in the pustules of $A$. psidii. 
in essential oils such as ortho-cymene, $\alpha$-pinene, and 1,8-cineole could clarify their roles in resistance and help in developing rapid screening tests for rust resistance. Testing additional clones would also be of great value in validating this technique as a screening test. Eucalyptus plants with a high limonene concentration in their essential oils could be used in breeding to obtain rust-resistant genetic material. E. grandis is considered to be highly susceptible to A. psidii
(Alfenas et al. 2009) and limonene was not present in its essential oil (Estanislau et al. 2001). E. urophylla, considered to be resistant to fungi (Alfenas et al. 2009), has limonene as one of the main constituents in its essential oil (Shieh 1998). Because clones C041A, VR3748, and TC31 are derived from the E. urophylla $\times$ E. grandis cross, the resistant clone may have inherited a higher quantity of limonene from E. urophylla than did the susceptible and highly
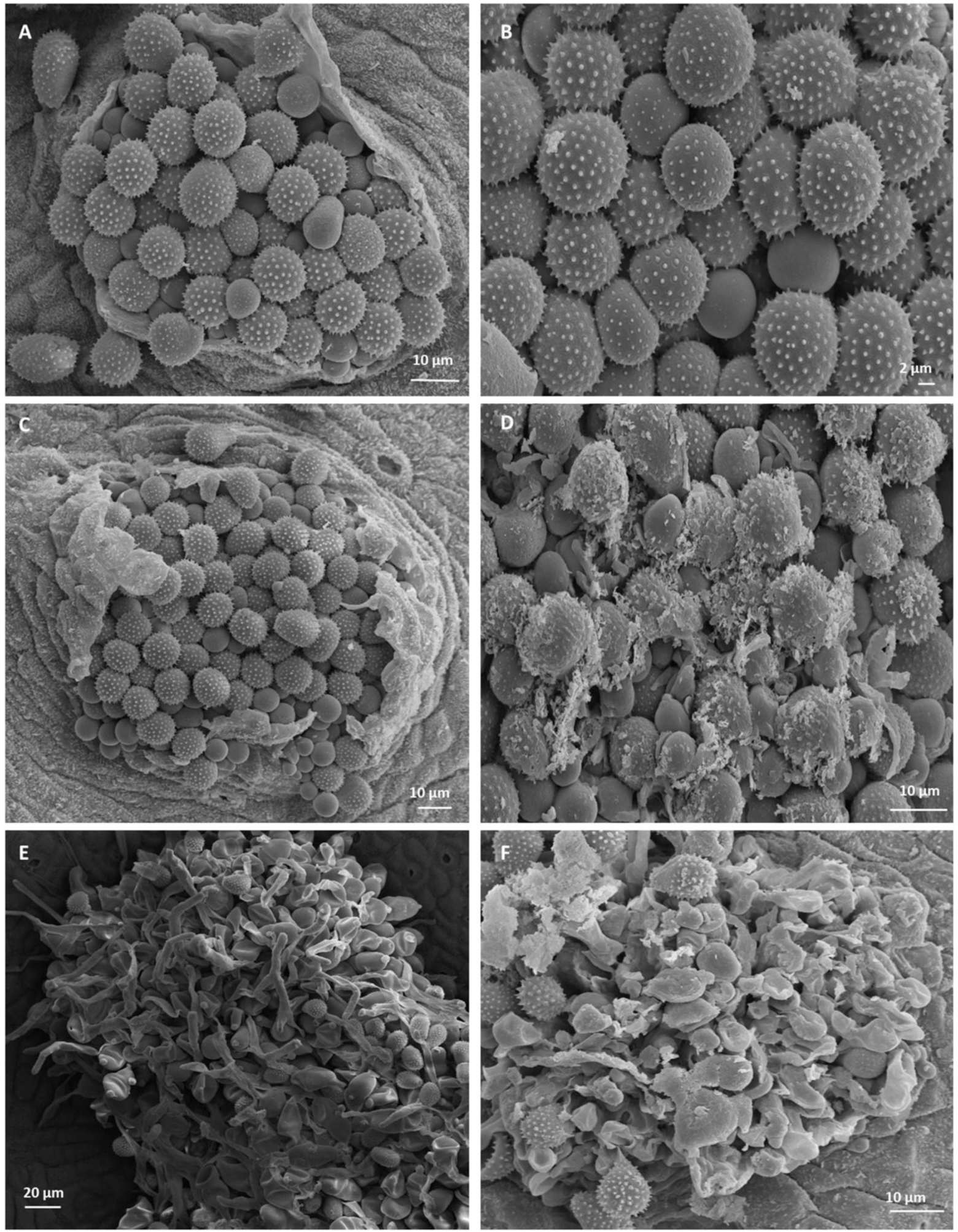

Fig. 4. Scanning electron microscopy images of Austropuccinia psidii pustules on Eucalyptus leaves treated with A, water containing $1 \%$ Tween 20 used as a control, B, $(R)$ (+)-limonene at $1 \mathrm{ppm}, \mathbf{C}, 10 \mathrm{ppm}, \mathbf{D}, 100 \mathrm{ppm}, \mathbf{E}, 1,000 \mathrm{ppm}$, and F, 10,000 ppm. At concentrations above $100 \mathrm{ppm}$, degeneration was observed in the urediniospore cell wall and collapse of the urediniospores, teliospores, and paraphyses. In the control treatment and at dosages of 1 and $10 \mathrm{ppm}$, no morphological alteration was observed in the pustules of $A$. psidii. 
susceptible clones. The hybrid of E. grandis and E. urophylla may have increased or decreased concentrations of these compounds and even other embedded constituents that are not present within each of the parental plant species. However, we cannot rule out the hypothesis of synergism of limonene and other compounds present in the essential oil on the resistance of Eucalyptus plants to A. psidii.

The essential oil composition of the three Eucalyptus clones analyzed was similar to that extracted from E. cinerea leaves with 1,8-cineole, $\alpha$-pinene, limonene, and $\alpha$-terpineol (Franco et al. 2005) and from E. urophylla with these compounds plus 4-terpineol and ocimene (Shieh 1998). The $\gamma$-terpinene, o-cymene, $\beta$-pinene, and 1,8-cineole are the main oil compounds of E. grandis leaves (Estanislau et al. 2001). This species, in Australia, has three monoterpenes, $\alpha$-pinene (22\%), 1,8-cineole (6\%), and $\alpha$-terpineol (5\%), and $\beta$-triketones, leptospermone, and flavosone as its major compounds (Boland et al. $1991)$, whereas 1,8-cineole, $\alpha$-pinene, $\beta$-pinene, $p$-cymene, $\alpha$-terpineol, and limonene were in general some of the principal oil compounds for 10 Eucalyptus species (E. alba, E. camadulensis, Corymbia citriodora, E. deglupta, E. globulus, E. propinqua, E. robusta, E. saligna, E. tereticornis, and E. urophylla) (Cimanga et al. 2002).

Differences in the essential oil compounds and yield from $E$. urophylla $\times E$. grandis are also important in identifying leaf pairs useful for oil extraction. Knowing the variations in concentration of chemical compounds in essential oil by clone is important to the various purposes of using these oils.

This research identified the variability in the quantity and quality of the essential oils of three Eucalyptus clones based on their genetic material and leaf stage. These findings may be associated, in conjunction with other factors, with resistance to A. psidii in the three hybrid $E$. urophylla $\times E$. grandis clones and their leaf phenological stages. This study provides evidence that limonene is fungitoxic to A. psidii urediniospores and, when found at high percentages in $\mathrm{Eu}$ calyptus leaves, is associated with rust resistance. This is the first work to demonstrate the relationship between the amount of limonene and essential oils in Eucalyptus leaves with rust resistance and the age-related resistance of their leaves. This biochemical marker may be important in identifying rust-resistant plant material in a genetic improvement program to develop Eucalyptus plants resistant to this major disease of Eucalyptus species.

\section{Acknowledgments}

The authors thank Global Edico Services and Dr. Phillip John Villani (University of Melbourne, Australia) who revised and corrected the English language used in this manuscript.

\section{Literature Cited}

Adams, R. P. 2007. Identification of Essential Oil Components by Gas Chromatography/Mass Spectrometry, 4th ed. Allured Publishing Corporation, Carol Stream, IL.

Aggarwal, K. K., Khanuja, S. P. S., Ahmad, A., Kumar, T. R. S., Gupta, V. K., and Kuma, S. 2002. Antimicrobial activity profiles of the two enantiomers of limonene and carvone isolated from the oils of Mentha spicata and Anethum sowa. Flavour Fragrance J. 17:59-63.

Alfenas, A. C., Zauza, E. A. V., Mafia, R. G., and Assis, T. F. 2009. Clonagem e doenças do eucalipto, 2nd ed. Editora UFV, Viçosa, Brazil.

Alfenas, A. C., Zauza, E. A. V., Wingfield, M. J., Roux, J., and Glen, M. 2005. Heteropyxis natalensis, a new host of Puccinia psidii rust. Australas. Plant Pathol. 34:285-286.

Amorim, E. P. D. R., Andrade, F. W. R. D., Moraes, E. M. D. S., Silva, J. C. D., Lima, R. D. S., and Lemos, E. E. P. D. 2011. Antibacterial activity of essential oils and extracts on the development of Ralstonia solanacearum in banana seedlings. Rev. Bras. Frutic. 33:392-398.

Andrés, M. F., Gonzalez-Coloma, A., Sanz, J., Burillo, J., and Sainz, P. 2012. Nematicidal activity of essential oils: A review. Phytochem. Rev. 11:371-390.

Batish, D. R., Singh, H. P., Kohli, R. K., and Kaur, S. 2008. Eucalyptus essential oil as a natural pesticide. For. Ecol. Manage. 256:2166-2174.

Batish, D. R., Singh, H. P., Setia, N., Kaur, S., and Kohli, R. K. 2006. Chemical composition and phytotoxicity of volatile essential oils from intact and fallen leaves of Eucalyptus citriodora. Z. Naturforsch. 61:465-471.

Beenken, L. 2017. Austropuccinia: A new genus name for the myrtle rust Puccinia psidii placed within the redefined family Sphaerophragmiaceae (Pucciniales). Phytotaxa 297:53-61.

Boava, L. P., Kuhn, O. J., Pascholati, S. F., Di Piero, R. M., and Furtado, E. L. 2010. Atividade de quitinases e peroxidases em folhas de eucalipto em diferentes estágios de desenvolvimento após tratamento com acibenzolar-
S-metil (ASM) e inoculação com Puccinia psidii. Trop. Plant Pathol. 35: 124-128.

Boland, D. J., Brophy, J. J., and House, A. P. N. 1991. Eucalyptus Leaf Oils: Use, Chemistry, Distillation and Marketing. Inkata Press, Sydney, Australia.

Box, G. E. P., and Cox, D. R. 1964. An analysis of transformations. J. R. Stat. Soc. Ser. B 26:211-252.

Brooker, M. I. H., and Kleinig, D. A. 2006. Field Guide to Eucalyptus, 3rd ed. Southeastern Australia, Bloomings, Melbourne.

Caccioni, D. R. L., and Guizzardi, M. 1994. Inhibition of germination and growth of fruit and vegetable postharvest pathogenic fungi by essential oil components. J. Essent. Oil Res. 6:173-179.

Cimanga, K., Kambu, K., Tona, L., Apers, S., De Bruyne, T., Hermans, N., Totte, J., Pieters, L., and Vlietinck, A. J. 2002. Correlation between chemical composition and antibacterial activity of essential oils of some aromatic medicinal plants growing in the Democratic Republic of Congo. J. Ethnopharmacol. 79:213-220.

Combrinck, S., Regnier, T., and Kamatou, G. P. P. 2011. In vitro activity of eighteen essential oils and some major components against common postharvest fungal pathogens of fruit. Ind. Crops Prod. 33:344-349.

Coutinho, T. A., Wingfield, M. J., Alfenas, A. C., and Crous, P. W. 1998 Eucalyptus rust: A disease with the potential for serious international implications. Plant Dis. 82:819-825.

da Silva, A. C., Andrade, P. M. T., Alfenas, A. C., Graça, R. N., Cannon, P., Hauff, R., Ferreira, D. C., and Mori, S. 2014a. Virulence and impact of Brazilian strains of Puccinia psidii on Hawaiian Ōhia (Metrosideros polymorpha). Pac. Sci. 68:47-56.

da Silva, A. C., Souza, P. E., Amaral, D. C., Zeviani, W. M., and Pinto, J. E. B. P. 2014b. Essential oils from Hyptis marrubioides, Aloysia gratissima and Cordia verbenacea reduce the progress of Asian soybean rust. Acta Sci. Agron. 36: 159-166.

da Silva, A. C., Souza, P. E., Pinto, J. E. B. P., Silva, B. M., Amaral, D. C., and Carvalho, E. A. 2012. Essential oils for preventative treatment and control of Asian soybean rust. Eur. J. Plant Pathol. 34:865-871

da Silva, A. C., Souza, P. E., Resende, M. L. V., Silva, M. B., Jr., Ribeiro, P. M., Jr., and Zeviani, W. M. 2014c. Local and systemic control of powdery mildew in eucalyptus using essential oils and decoctions from traditional Brazilian medicinal plants. For. Pathol. 44:145-153.

Dianese, J. C., Moraes, T. S. A., and Silva, A. R. 1986. Screening Eucalyptus species for rust resistance in Bahia, Brazil. Trop. Pest Manage. 32:292-295.

Droby, S., Eick, A., Macarisin, D., Cohen, L., Rafael, G., Stange, R., McColum, G., Dudau, N., Nasser, A., Wisniewski, M., and Shapira, R. 2008. Role of citrus volatiles in host recognition, germination and growth of Penicillium digitatum and Penicillium italicum. Postharvest Biol. Technol. 49:386-396.

Eckert, J. W., Ratnayake, M., and Gutter, Y. 1984. Volatiles from wounded citrus fruits stimulate germination of Penicillium digitatum conidia. Phytopathology (abstr.) $74: 793$

Elaissi, A., Medini, H., Marzouki, H., Larbi Khouja, M., Lynene, F., Chemli, R., and Harzallah-Skhiri, F. 2010. Variation in volatile leaf oils of twelve Eucalyptus species harvested from Hajeb Layoun Arboreta (Tunisia). Chem. Biodivers. 7:705-716.

Estanislau, A. A., Barros, F. A. S., Pena, A. P., Santos, S. C., Ferri, P. H., and Paula, J. R. 2001. Composição química e atividade antibacteriana dos óleos essenciais de cinco espécies de Eucalyptus cultivadas em Goiás. Rev. Bras. Farmacogn. 11:95-100.

Fiori, A. C. G., Schwan-Estrada, K. R. F., Stangarlin, J. R., Vida, J. B., Scapim, C. A., Cruz, M. E. S., and Pascholati, S. F. 2000. Antifungal activity of leaf extracts and essential oils of some medicinal plants against Didymella bryoniae. Plant Pathol. 148:483-487.

Franco, J., Boller, C., Franco, L., and Nakashima, T. 2005. Composição química e atividade antimicrobiana in vitro do óleo essencial de Eucalyptus cinerea F. Mull. ex Benth., Myrtaceae, extraído em diferentes intervalos de tempo. Rev. Bras. Farmacogn. 15:191-194

French, R. C., Long, R. K., Latterell, F. M., Graham, C. L., Smoot, J. J., and Shaw, P. E. 1978. Effect of nonanal, citral, and citrus oils on germination of conidia of Penicillium digitatum and Penicillium italicum. Phytopathology 68:877-882.

Glen, M., Alfenas, A. C., Zauza, E. A. V., Wingfield, M. J., and Mohammed, C. 2007. Puccinia psidii: A threat to the Australian environment and economy a review. Australas. Plant Pathol. 36:1-16.

Hammer, K. A., Carson, C. F., and Riley, T. V. 2003. Antifungal activity of the components of Melaleuca alternifolia (tea tree) oil. J. Appl. Microbiol. 95: 853-860.

Hantao, L. W., Ribeiro, F. A. L., Passador, M. M., Furtado, E. L., Poppi, R. J., Gozzo, F. C., and Augusto, F. 2014. Metabolic profiling by ultraperformance liquid chromatography-mass spectrometry and parallel factor analysis for determination of disease biomarkers in Eucalyptus. Metabolomics 10:1318-1325.

Junghans, D. T., Alfenas, A. C., Brommonschenkel, S. H., Oda, S., Mello, E. J., and Grattapaglia, D. 2003. Resistance to rust (Puccinia psidii Winter) in Eucalyptus: Mode of inheritance and mapping of a major gene with RAPD markers. Theor. Appl. Genet. 108:175-180.

Laia, M. L., Alfenas, A. C., Brommonschenkel, S. H., Oda, S., Melo, E. J., Silva, I. M. A., Gonçalves, J. F., and Marques, A. 2015. Cloning and characterization 
of gene-resistant analogs (RGAs) involved in rust (Puccinia psidii) resistance in Eucalyptus grandis. J. For. Res. 26:711-718.

Machado, P. S., Glen, M., Pereira, O. L., Silva, A. A., and Alfenas, A. C. 2015. Epitypification of Puccinia psidii, causal agent of guava rust. Trop. Plant Pathol. 40:5-12.

Mamani, E. M. C., Bueno, N. W., Faria, D. A., Guimarães, L. M. S., Lau, D., Alfenas, A. C., and Grattapaglia, D. 2010. Positioning of the major locus for Puccinia psidii rust resistance (Pprl) on the Eucalyptus reference map and its validation across unrelated pedigrees. Tree Genet. Genomes 6:953-962.

National Institute of Standards and Technology. 1998. PC Version of the NIST/ EPA/NIH Mass Spectral Database. U.S. Department of Commerce, Gaithersburg, MD.

Oluma, H. O. A., and Garba, I. U. 2004. Screening of Eucalyptus globulus and Ocimum gratissimum against Pythium aphanidermatum. Niger. J. Plant Prot. 21:109-114.

Parbery, D. G., and Blakeman, J. P. 1978. Effect of substances associated with leaf surfaces on appressorium formation by Colletotrichum acutatum. Trans. Br. Mycol. Soc. 70:7-19.

Pereira, R. B., Lucas, G. C., Perina, F. J., Resende, M. L. V., and Alves, E. 2011. Potential of essential oils for the control of brown eye spot in coffee plants. Cienc. Agrotec. 35:115-123.

Pérez, C. A., Wingfield, M. J., Altier, N. A., Simeto, S., and Blanchette, R. A. 2011. Puccinia psidii infecting cultivated Eucalyptus and native Myrtaceae in Uruguay. Mycol. Prog. 10:273-282.

Regnier, T., Du Plooy, W., Combrinck, S., and Botha, B. 2008. Fungitoxicity of Lippia scaberrima essential oil and selected terpenoid components on two mango postharvest spoilage pathogens. Postharvest Biol. Technol. 48:254-258.

Romagnoli, C., Bruni, R., Andreotti, E., Rai, M. K., Vicentini, C. B., and Mares, D. 2005. Chemical characterization and antifungal activity of essential oil of capitula from wild Indian Tagetes patula L. Protoplasma 225:57-65.

Santos, I. B., Lopes, M. S., Bini, A. P., Tschoeke, B. A. P., Verssani, B. A. W., Figueredo, E. F., Cataldi, T. R., Marques, J. P. R., Silva, L. D., Labate, C. A., and Quecine, M. C. 2019. The Eucalyptus cuticular waxes contribute in preformed defense against Austropuccinia psidii. Front. Plant Sci. 9:1978.

Santos, M. R., Guimarães, L. M. S., Resende, M. D. V., Rosse, L. N., Zamprogno, K. C., and Alfenas, A. C. 2014. Resistance of Eucalyptus pellita to rust (Puccinia psidii). Crop Breed. Appl. Biotechnol. 14:244-250.

Sharma, N., and Tripathi, A. 2006. Fungitoxicity of the essential oil of Citrus sinensis on post-harvest pathogens. World J. Microbiol. Biotechnol. 22: 587-593.

Shieh, J. C. 1998. Yields and chemical components of essential oils in Eucalyptus urophylla leaves. Taiwan J. For. Sci. 13:291-300.

Silva, P. H. M., Miranda, A. C., Moraes, M. L. T., Furtado, E. L., Stape, J. L., Alvares, C. A., Sentelhas, P. C., Mori, E. S., and Sebbenn, A. M. 2013.
Selecting for rust (Puccinia psidii) resistance in Eucalyptus grandis in São Paulo State, Brazil. For. Ecol. Manag. 303:91-97.

Silva, R. R., Silva, A. C., Rodella, R. A., Serrão, J. E., Zanuncio, J. C., and Furtado, E. L. 2017. Pre-infection stages of Austropuccinia psidii in the epidermis of Eucalyptus hybrid leaves with different resistance levels. Forests 8:362.

Singh, P., Shukla, R., Prakash, B., Kumar, A., Singh, S., Mishra, P. K., and Dubey, N. K. 2010. Chemical profile, antifungal, antiaflatoxigenic and antioxidant activity of Citrus maxima Burm. and Citrus sinensis (L.) Osbeck essential oils and their cyclic monoterpene, DL-limonene. Food Chem. Toxicol. 48: 1734-1740.

Sneath, P. H. A., and Sokal, R. R. 1973. Numerical Taxonomy. W.H. Freeman, San Francisco, CA.

Stockigt, J., Oblitz, P., Falkenhagen, H., Lutterbach, R., and Endeß, S. 1995. Natural products and enzymes from plant cell cultures. Plant Cell Tiss. Org. Cult. 43:97-109.

Sudha, G., and Ravishankar G. A. 2002. Involvement and interaction of various signaling compounds on the plant metabolic events during defense response, resistance to stress factors, formation of secondary metabolites and their molecular aspects. Plant Cell Tiss. Org. Cult. 71:181-212.

Taylor, J., and Mims, C. W. 1991. Infection of and colony development within leaves of susceptible and resistant pearl millet and two nonhost by the rust fungus Puccinia substriata var. indica. Mycologica 83:565-577.

Van den Dool, E., and Kratz, P. D. 1963. A generalization of the retention index system including linear temperature programmed gas-liquid partition chromatography. J Chromatogr. 11:463-471.

Vilela, G. R., Almeida, G. S., D’Acre, M. A. B. R., Moraes, M. H. D., Brito, J. O., Silva, M. F. G. F., Silva, S. C., de Stefano Piedade, S. M., Calori-Domingues, M. A., and da Gloria, E. M. 2009. Activity of essential oil and its major compound, 1,8-cineole, from Eucalyptus globulus Labill., against the storage fungi Aspergillus flavus Link and Aspergillus parasiticus Speare. J. Stored Prod. Res. 45:108-111.

Wilson, C. L., Solar, J. M., Ghaouth, A. E. L., and Wisniewski, M. E. 1997. Rapid evaluation of plant extracts and essential oils for antifungal activity against Botrytis cinerea. Plant Dis. 81:204-210.

Xavier, A. A., Alfenas, A. C., Matsuoka, K., and Hodges, C. S. 2001. Infection of resistant and susceptible Eucalyptus grandis genotypes by urediniospores of Puccinia psidii. Australas. Plant Pathol. 30:277-281.

Xavier, A. A., da Silva, A. C., Guimarães, L. M. S., Matsuoka, K., Hodges, C. S. and Alfenas, A. C. 2015. Infection process of Puccinia psidii in Eucalyptus grandis leaves of different ages. Trop. Plant Pathol. 40:318-325.

Zamprogno, K. C., Furtado, E. L., Marino, C. L., Bonine, C. A. V., and Dias, D. C. 2008. Utilização de análise de segregantes agrupados na identificação de marcadores ligados a genes que controlam a resistência à ferrugem (Puccinia psidii Winter) em Eucalyptus sp. Summa Phytopathol. 34:253-255. 